Journal of Agricultural Sciences
(Tarim Bilimleri Dergisi)

\title{
Proximate Composition, Fatty Acid and Amino Acid Profiles of Narrow-Barred Spanish Mackerel (Scomberomorus commerson) Fillets from İskenderun Bay in The North-Eastern Mediterranean Sea
}

\author{
Hatice Asuman YILMAZa iD \\ $a^{*}$ Çukurova University, Faculty of Fisheries, Department of Aquaculture, 01330, Adana, TURKEY

\section{ARTICLE INFO} \\ Research Article \\ Corresponding Author: Hatice Asuman YILMAZ, E-mail: ayilmaz@cu.edu.tr \\ Received: 16 June 2020 / Revised: 30 July 2020 / Accepted: 03 August 2020 / Online: 04 December 2021
}

\section{ABSTRACT}

The present study aims to determine the proximate, fatty acid and amino acid profiling of consumed fresh narrow-barred Spanish mackerel (Scomberomorus commerson). Landed fish were freshly sampled (total length 33.7-48.7 $\mathrm{cm}$ and weight 617-1260 g) from the Yumurtalık Bay (north-eastern Mediterranean Sea) in Turkey during January, February and March. The protein values were highest in January $(22.89 \%)$ while the and lowest in February (21.38\%) and March (21.73\%). Lipid and ash values were not significantly differencing among sampling time. The fatty acid data revealed that the saturated fatty acid values were found higher than the polyunsaturated and monounsaturated fatty acid values. In general, the fillets were abundant in palmitic acid (C16:0), stearic acid (C18:0), oleic acid (18:1n-9) and docosapentaenoic acid (C22:6n-3; DHA) values, regardless of the sampled months. DHA value was

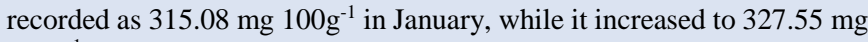
$100 \mathrm{~g}^{-1}$ in the March samples. A total of 16 amino acids were determined from the fresh fillets. Compared with the other essential amino acids, the concentration of lysine and leucine were found to be higher in the fillet. At the same time, the lower rates of tryptophan were detected in examined samples for all months. Consequently, this study shows that the narrowbarred Spanish mackerel as a finfish (commercially valuable) from the north-eastern Mediterranean Sea has precious nutritional values that of the protein, fatty acids and amino acids during the sampling period. This fish can be recommended in terms of detected essential fatty acid and amino acid profile that completely nutritious for the human as well as other organisms' dietary requirements.

Keywords: Essential amino acids, Fatty acids, Proximate composition, Scomberomorus commerson

(C) Ankara University, Faculty of Agriculture

\section{Introduction}

Narrow-barred Spanish mackerel is a member of the Scombridae family, and it is usually found in a large area centered in world especially Southeast Asia and the fish migrate to the eastern Mediterranean Sea via the Suez Canal and move westward toward Tunisia (Froese \& Pauly 2019). In the Mediterranean Sea, the presence of narrow-barred Spanish mackerel was first recorded in Palestine (Hornell 1935), whereas its presence has been known in the Mersin and Iskenderun Bays, Turkey, since 1981 (Gücü et al. 1994). Moreover, the presence of this fish was last recorded in the northern Aegean Sea in Izmir Bay in 2018 (Akyol and Tosunoğlu 2019). This immigrant fish species is consumed by hunting. This pelagic fish is increasingly being caught by commercial fisheries, and it has often been reported to be caught by the local fisheries of Güllük, Gökova and Mersin Gulfs (Gücü et al. 1994; Torcu et al. 1997).

Fish are an important source of protein, play an important role in human nutrition and possess high digestibility, biological and growth-promoting values. Fish are also the source of essential elements, particularly n-3 polyunsaturated fatty acids (n-3 PUFAs). Such fatty acids present in fish, especially docosahexaenoic acid, are beneficial for the development of the brain and visual system in infants as well as for reducing the incidence of various disorders in adults, including high cholesterol levels, stroke and heart diseases (Von Schacky et al. 1999; Connor 2000; Arts et al. 2001; Lauritzen et al. 2001; Nordov et al. 2001; Silvers \& Scott 2002).

During the last two decades, PUFAs have attracted a great interest among scientists for their medicinal and nutritional properties. The abundance of unsaturated fatty acids is the most valuable characteristic of the fish (Nordov et al. 2001; Türkmen et al. 2008). Polyunsaturated fatty acids of the $\omega-6$ and $\omega-3$ families in particular are recognized as essential biochemical components of the human diet (Aktaş \& Halperin 2004). Therefore, the approximate biochemical composition of one species helps evaluate its nutritional and edibility in terms of energy units in comparison with those of other species. Information about the biochemical composition of Scomberomorus commerson is of great importance in assessing its nutritional value, but it also 
facilitates quality assessment and optimum use of this natural resource. However, no information is available regarding the biochemical composition of $S$. commerson. This study was aimed at determining the changes in the proximate fatty acid (FA) and amino acid composition in fillets of fish whose prevalence continues to rapidly increase in the Yumurtalık Bay, Adana, Turkey. To the best of our knowledge, this is the first report to investigate the proximate composition, fatty acid and amino acids profile of these fish species from İskenderun Bay in The North-Eastern Mediterranean Sea caught during the consumption months.

\section{Material and Methods}

The research was conducted from January to March 2019. Sampling of mackerel fish was performed in Yumurtalık Bay, Adana, Turkey. Narrow-barred Spanish mackerel were caught by professional fishermen at the coast of the Mediterranean of Turkey (Figure 1). The months when the fish were caught at the Mediterranean shores were January, February and March (İsmail Kamburlu (fishermen), pers comn.). Six samples of the fish species caught during each of these three months in 2019 (18 samples) were placed in styrofoam in box with ice and brought to the laboratory within 2 hours and stored at $-20^{\circ} \mathrm{C}$ until analysis. The min-max length and weight of the narrow-barred Spanish mackerel were 33.7-48.7 $\mathrm{cm}(40.83 \pm 1.15)$ and $617-1260 \mathrm{~g}$ (935.16 \pm 62.52$)$, respectively. The muscle tissues of fish were homogenized, manually separated and analyses in triplicate with regard to nutritional value, fatty acid composition and amino acid composition.

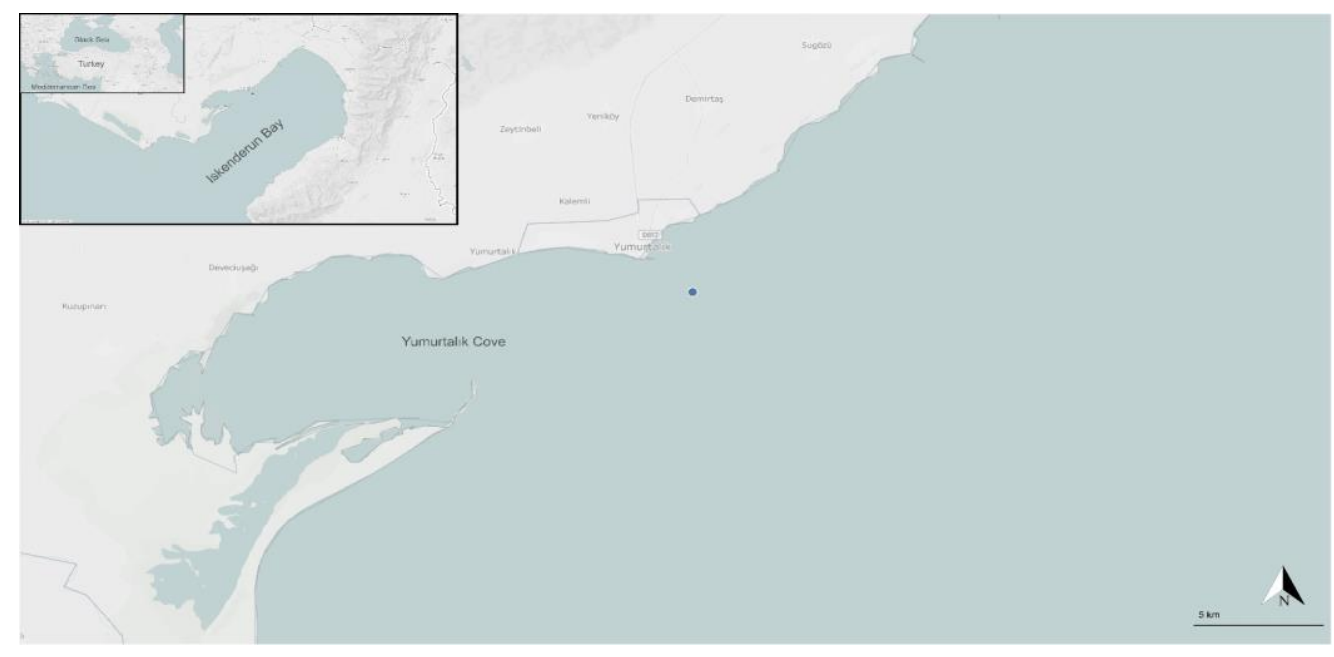

Figure 1- Map of the fish catching area

\subsection{Chemical analyses}

The samples were thawed at $+4{ }^{\circ} \mathrm{C}$ and 6 fish fillet samples from each month were homogenized using a blender. Proximate composition analysis (moisture, ash, lipid, and crude protein) of the homogenized samples was determined using the standard procedures of AOAC (1995).

Moisture content was measured by drying samples to constant weight at $103{ }^{\circ} \mathrm{C}$ for $24 \mathrm{~h}$. Ash content was determined by burning the samples at $600{ }^{\circ} \mathrm{C}$ for $5 \mathrm{~h}$. Protein $(\mathrm{N} \times 6.25)$ content was determined using an automated Kjeldahl Kjeltec 2200 (Foss Tecator, Högans, Sweden).

\subsection{Analytical methods}

Lipids were extracted according to the procedure described by Folch et al. (1957). Following lipid extraction, fatty acid methyl esters (FAME) were prepared according to the method described by Metcalfe and Schmitz (1961) and analysed as previously described (Czesny and Dabrowski 1998) with some modifications. Briefly, FAME obtained were separated in a gas chromatographic column (Agilent $6820 \mathrm{~A}$ ), which was equipped with a flame ionization detector and fitted with a DB 23 capillary column $(60 \mathrm{~m}, 0.25 \mathrm{~mm}$ i.d. and $0.25 \mu \mathrm{m})$. The injector temperature program involved maintenance of $190{ }^{\circ} \mathrm{C}$ for $35 \mathrm{~min}$, followed by temperature increase at a rate of $30^{\circ} \mathrm{C}$ min- 1 to $220^{\circ} \mathrm{C}$ where it was maintained for 5 min. Carrier gas was hydrogen ( $2 \mathrm{~mL}$ min-1), with a split ratio of 30:1. The individual fatty acids were identified by comparing their retention times with that of a standard mix of fatty acids (Supelco 37 component FAME mix). Amino acid composition analysis of the fish fillet samples was conducted using the Ultra-Fast Liquid Chromatography system equipped with a UV detector (Gheshlaghi et al. 2008).

Fatty acids per $100 \mathrm{~g}$ of total lipid (TL) require to be the derivation of a reasonable factor (F) correlating the total quantity of fatty acids to a given quantity of total lipid (Weihrauch et al. 1977). Fatty acids in fish muscle levels $\left(\mathrm{mg}^{\left.100 \mathrm{~g}^{-1}\right)}\right.$ were converted with them following formula: 
$\mathrm{FA}\left(\mathrm{mg} 100 \mathrm{~g}^{-1}\right)=(\mathrm{F} \mathrm{X} \mathrm{FA} \cdot \mathrm{TL}) \cdot 10^{3}$

In these conversions, $\mathrm{F}$ indicates fatty acid conversion factor $(0.90$ for fish with $5 \%$ fat; for fish with $<5 \%$ fat, it is calculated from the equation $\mathrm{F}=0.933-(0.143-\mathrm{TL}))$. FA represents fatty acids. TL represents the total lipids.

The atherogenicity index (AI), thrombogenicity index (TI) and peroxidisability index (PI) were calculated by following the equation suggested by Ulbricht and Southgate (1991) and making slight modifications to it as described by Canto et al. (2015). The hypocholesterolaemic to hypercholesterolaemic ratio $(\mathrm{H} / \mathrm{H})$ was calculated using the formula developed by Santos-Silva et al. (2002).

\subsection{Statistical analysis}

The proximate compositions of amino acids and fatty acids $(n=6)$ have been reported as mean \pm standard deviation values. Data were analyzed using the one-way analysis of variance (ANOVA) test at a significance level of $0.05 \%$ after confirmation of normality and homogeneity of variance. When significant differences were detected, data were subjected to Student-NewmanKeuls post hoc test for identifying homogeneous subsets. All computations were performed using SPSS16.0 (SPSS Inc. Chicago, IL, USA).

\section{Results and Discussion}

\subsection{Proximate composition of narrow-barred Spanish mackerel}

Caught during the consumption months of the narrow-barred Spanish mackerel are given in Table 1. Landed fish were during the months of January, February and March, and statistical differences $(\mathrm{P}<0.05)$ were noted for moisture and protein value. The value of moisture in fish fillet usually determines its nutritional taste and value (Gökoğlu et al. 2004). Comparisons made among the groups of narrow-barred Spanish mackerel caught on each of the months revealed that the highest moisture value was found in the February and March samples (73.36 and 73.97\%, respectively), and the lowest value was found in the January sample (72.64\%). Moisture value in fish effects of the textural properties are very high, the fish will have a soft and mushy texture (Lazo et al. 2017). Moreover, measurement of ash value is mostly dependent on the mineral values in each fish sample as well as the feeding patterns, growth phase, seasons and habitat or environment of the fish species (Suryaningrum et al. 2010). Moisture value in the samples will also have a large impact on the protein value measured in the fish and the higher protein value in the samples will result in a lower moisture value than in fresh samples (Gökoğlu et al. 2004; Sebranek 2009). Protein value was the highest in the January sample (22.89\%) compared with that in the other 2 months, followed by the February $(21.39 \%)$ and March (21.73\%) samples. Bandarra et al. (2001) and Çelik (2008) found similar results and reported the protein content of horse mackerel. Reduction of muscle protein in adult fish has been mentioned in cases of mobilization under prolonged fasting (Love, 1992). However, there have been some cases where seasonal protein changes have been reported for wild fish populations (Gökçe et al. 2004; Patrick et al. 2008).

Table 1- Proximate composition (\%) of narrow-barred Spanish Mackerel during the sampling periods

\begin{tabular}{cccc}
\hline \multirow{2}{*}{ Proximate Composition } & \multicolumn{3}{c}{ Sampling Time } \\
\cline { 2 - 4 } & 19 - January & 19 -February & 19 - March \\
\hline Moisture & $72.64 \pm 1.09^{\mathrm{b}}$ & $73.36 \pm 0.42^{\mathrm{a}}$ & $73.97 \pm 0.56^{\mathrm{a}}$ \\
Ash & $3.01 \pm 0.21$ & $2.97 \pm 0.10$ & $2.99 \pm 0.13$ \\
Protein & $22.89 \pm 0.63^{\mathrm{a}}$ & $21.39 \pm 0.38^{\mathrm{b}}$ & $21.73 \pm 0.91^{\mathrm{b}}$ \\
Lipid & $2.06 \pm 0.10$ & $2.11 \pm 0.20$ & $2.06 \pm 0.01$ \\
\hline
\end{tabular}

For the data relative to fish fillet, values are mean $\pm S D$. $(n=6$; number of fishes per sampling time), and values in the same row with different superscript letters indicate statistically significant difference $(\mathrm{P}<0.05)$

Monthly sampling did not significantly $(\mathrm{P}>0.05)$ affect the lipid value in the flesh. All the other species exhibited fillet fat of $<1 \%$, which would categorize them into low-fat species (Huynh and Kitts 2009). The lipid value of fish is also attributed to environmental factors like nutritional supply and food sources and directly affects odor and flavor density (Puwastien et al. 1999; Lazo et al. 2017; Vijayan et al. 2016).

\subsection{Fatty Acid Composition of narrow-barred Spanish mackerel}

The fatty acid composition of narrow-barred Spanish mackerel caught during the consumption months is shown in Table 2. At all sampling time, narrow-barred Spanish mackerel showed the highest levels of total saturated fatty acids (SFAs), followed by PUFAs and monounsaturated fatty acids (MUFAs). In agreement with our results, Rajaram et al. (2018) and Osman et al. (2001) reported similar predominant FAs as well as equivalent SFA-PUFA-MUFA patterns in Spanish mackerel fillets. The fatty acid 
compositions varied during the sampling time. The fatty acid composition of fish flesh in March samples had the highest $(\mathrm{P}<0.05)$ levels of total saturates. The SFA value of narrow-barred Spanish mackerel in the March sample was $286.95 \mathrm{mg}^{100 \mathrm{~g}^{-1}}$ followed

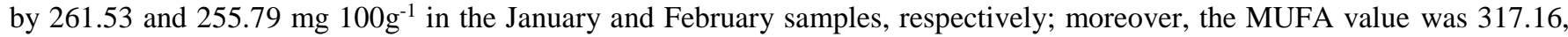

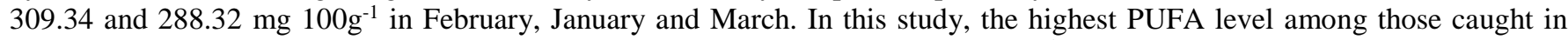

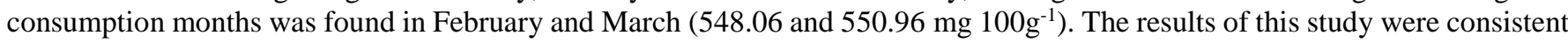
with the results of various studies in the northeastern Mediterranean (Ozogul et al. 2009; Durmuş 2018; Köşker 2020) There is a common view of the positive effects of PUFAs on human health (Lunn and Theobald 2006; Fung et al. 2009; Hellberg et al. 2012). The accumulation of fatty acids in fish muscle is affected by various factors such as diet and genetics, as well as sexual maturity, geographical location and hunting season (Horn et al. 2018).

In general, viewed individually fatty acids, including palmitic acid, stearic acid, oleic acid and DHA were abundantly found in narrow-barred Spanish mackerel flesh, independent of the sampling time. Prato and Biandolino (2012) also reported oleic acid as the most abundant of the MUFAs in most marine fishes. MUFA and SFA are used as metabolic energy sources for these species, and long chain n-3 fatty acids are essentially essential for structural purposes, namely as components of membrane phospholipids. Moreover, MUFA are more efficiently transformed into energy via the process of $\beta$-oxidation than n-6 PUFA (Turchini et al. 2007). This observation can be explained by the fact that SFA and MUFA are largely represented in neutral lipids and are more prone to migration (Turchini et al. 2007).

Table 2- Fatty acids (mg/100g) composition of narrow-barred Spanish Mackerel

\begin{tabular}{|c|c|c|c|}
\hline \multirow[t]{2}{*}{ Fatty Acids } & \multicolumn{3}{|c|}{ Sampling Time } \\
\hline & 19- January & 19- February & 19-March \\
\hline C14:0 & $11.35 \pm 1.65$ & $11.81 \pm 1.56$ & $11.23 \pm 0.41$ \\
\hline C15:0 & $7.44 \pm 1.73$ & $7.39 \pm 1.08$ & $8.98 \pm 0.14$ \\
\hline C16:0 & $373.08 \pm 5.89^{b}$ & $429.50 \pm 5.41^{\mathrm{a}}$ & $398.32 \pm 5.52^{\mathrm{ab}}$ \\
\hline C18:0 & $261.53 \pm 5.78^{b}$ & $255.79 \pm 4.84^{\mathrm{b}}$ & $286,95^{\mathrm{a}} \pm 4.16^{\mathrm{a}}$ \\
\hline C20:0 & $10.81 \pm 0.07^{\mathrm{b}}$ & $15.14 \pm 0.80^{\mathrm{a}}$ & $10.58 \pm 0.17^{b}$ \\
\hline $\mathrm{C} 22: 0$ & $11.88 \pm 0.43^{\mathrm{a}}$ & $10.54 \pm 0.37^{b}$ & $10.98 \pm 0.17^{\mathrm{b}}$ \\
\hline $\mathrm{C} 24: 0$ & $1.68 \pm 0.01^{\mathrm{ab}}$ & $2.25 \pm 0.19^{\mathrm{a}}$ & $1.10 \pm 0.20^{\mathrm{b}}$ \\
\hline SFA & $685.68 \pm 10.37^{b}$ & $741.00 \pm 9.06^{\mathrm{a}}$ & $735.97 \pm 10.04^{\mathrm{a}}$ \\
\hline C14:1 & $1.95 \pm 0.17$ & $2.00 \pm 0.37$ & $2.01 \pm 0.01$ \\
\hline C15:1 & $2.89 \pm 0.17^{\mathrm{b}}$ & $3.49 \pm 0.48^{\mathrm{a}}$ & $2.78 \pm 0.01^{\mathrm{b}}$ \\
\hline C16:1 & $58.90 \pm 2.30^{\mathrm{b}}$ & $64.88 \pm 0.62^{\mathrm{a}}$ & $61.46 \pm 0.45^{\mathrm{ab}}$ \\
\hline C17:1 & $6.44 \pm 0.65^{\mathrm{b}}$ & $7.99 \pm 0.07^{\mathrm{a}}$ & $5.85 \pm 0.09^{\mathrm{b}}$ \\
\hline C18:1n9 & $158.85 \pm 3.85^{\mathrm{a}}$ & $147.53 \pm 0.07^{b}$ & $131.16 \pm 5.85^{\mathrm{c}}$ \\
\hline C18:1n7 & $58.33 \pm 3.92$ & $61.52 \pm 3.39$ & $61.66 \pm 3.14$ \\
\hline C20:1n9 & $9.45 \pm 0.57^{c}$ & $16.23 \pm 1.04^{\mathrm{a}}$ & $10.75 \pm 0.17^{\mathrm{b}}$ \\
\hline $\mathrm{C} 22: \ln 9$ & $4.37 \pm 0.13$ & $4.93 \pm 0.47$ & $4.40 \pm 0.07$ \\
\hline $\mathrm{C} 24: \ln 9$ & $7.03 \pm 0.48$ & $7.63 \pm 0.07$ & $7.16 \pm 0.43$ \\
\hline MUFA & $309.34 \pm 3.72$ & $317.166 \pm 1.76$ & $288.32 \pm 8.90$ \\
\hline C18:2n6 & $17.19 \pm 0.01^{\mathrm{c}}$ & $17.22 \pm 0.01^{\mathrm{b}}$ & $17.48 \pm 0.02^{\mathrm{a}}$ \\
\hline C18:3n6 & $7.47^{\mathrm{a}} \pm 1.33^{\mathrm{ab}}$ & $7.67^{\mathrm{a}} \pm 1.47$ & $5.94 \pm 0.09^{b}$ \\
\hline $\mathrm{C} 18: 3 \mathrm{n} 3$ & $75.55 \pm 4.71$ & $77.39 \pm 3.87$ & $77.37 \pm 2.04$ \\
\hline C20:2n6 & $3.49 \pm 0.26$ & $3.50 \pm 0.26$ & $3.61 \pm 0.02$ \\
\hline $\mathrm{C} 20: 3 \mathrm{n} 6$ & $11.43 \pm 0.07$ & $11.73 \pm 0.10$ & $10.41 \pm 1.10$ \\
\hline C20:4n6 & $3.01 \pm 0.00^{\mathrm{a}}$ & $3.10 \pm 0.03^{\mathrm{a}}$ & $2.91 \pm 1.11^{\mathrm{b}}$ \\
\hline $\mathrm{C} 20: 5 \mathrm{n} 3$ & $67.32 \pm 4.66$ & $67.62 \pm 3.79$ & $68.44 \pm 4.74$ \\
\hline $\mathrm{C} 22: 5 \mathrm{n} 3$ & $26.48 \pm 1.49$ & $27.40 \pm 1.25$ & $25.11 \pm 0.38$ \\
\hline $\mathrm{C} 22: 6 \mathrm{n} 3$ & $315.08 \pm 9.38^{b}$ & $322.76 \pm 2.78^{\mathrm{ab}}$ & $327.55 \pm 3.94^{\mathrm{a}}$ \\
\hline PUFA & $535.04 \pm 1.35^{\mathrm{b}}$ & $548.06 \pm 4.97^{\mathrm{a}}$ & $550.96 \pm 7.66^{\mathrm{a}}$ \\
\hline $\mathrm{EPA}+\mathrm{DHA}$ & $382.40 \pm 8.22^{b}$ & $391.37 \pm 5.11^{\mathrm{a}}$ & $392.42 \pm 3.15^{\mathrm{a}}$ \\
\hline PUFA/SFA & $0.78 \pm 0.04$ & $0.74 \pm 0.01$ & $0.74 \pm 0.04$ \\
\hline n6 & $42.60 \pm 1.18^{\mathrm{a}}$ & $43.19 \pm 1.82^{\mathrm{a}}$ & $39.83 \pm 0.54^{\mathrm{b}}$ \\
\hline n3 & $484.43 \pm 11.41^{b}$ & $496.26 \pm 1.87^{\mathrm{a}}$ & $497.94 \pm 4.14^{\mathrm{a}}$ \\
\hline n6/n3 & $0.09 \pm 0.01$ & $0.10 \pm 0.01$ & $0.10 \pm 0.00$ \\
\hline $\mathrm{n} 3 / \mathrm{n} 6$ & $11.39 \pm 0.95$ & $11.51 \pm 0.53$ & $12.36 \pm 0.04$ \\
\hline DHA/EPA & $4.68 \pm 0.12$ & $4.76 \pm 0.17$ & $4.82 \pm 0.29$ \\
\hline IA & $0.81 \pm 0.04$ & $0.86 \pm 0.01$ & $0.87 \pm 0.05$ \\
\hline IT & $0.29 \pm 0.02$ & $0.31 \pm 0.00$ & $0.31 \pm 0.02$ \\
\hline PI & $1.02 \pm 0.06^{\mathrm{a}}$ & $0.91 \pm 0.04^{\mathrm{b}}$ & $0.99 \pm 0.04^{\mathrm{a}}$ \\
\hline $\mathrm{HH}$ & $1.62 \pm 0.11^{\mathrm{a}}$ & $1.41 \pm 0.02^{\mathrm{b}}$ & $1.49 \pm 0.07^{b}$ \\
\hline
\end{tabular}

For the data relative to fish fillet, values are mean $\pm \mathrm{SD} .(\mathrm{n}=6$; number of fishes per sampling time); and values in the same row with different superscript letters indicate statistically significant difference $(\mathrm{P}<0.05)$ 
In the fatty acid analyses of narrow-barred Spanish mackerel, the predominant SFAs were palmitic acids and stearic acid. Generally, the palmitic acid value in fish was considerably higher than the stearic acid value at all sampling time. Oleic acid was the most abundant fatty acid of the MUFAs in flesh of fish and statistically different in those caught in consumption months, the

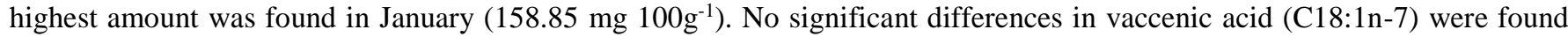
among the fish samples of each month. Linoleic acid (C18:2n-6) value in fish was significantly higher in the March sample

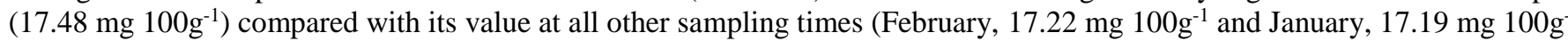
$\left.{ }^{1}\right)$. Osman et al. (2001) also reported high linoleic acid values in comparison with other n-6 fatty acids for fish species with low fat contents from tropical marine waters. In addition, linoleic acid and $\alpha$-linolenic acid (18:3n-3) PUFAs are essential nutrients that must be obtained from food (Das 2006).

There were no significant differences in either the $\alpha$-linolenic acid or EPA value among all sampling times (Table 2). The EPA value of narrow-barred Spanish mackerel was almost the same at all sampling times and EPA ratios in the range of 67.32

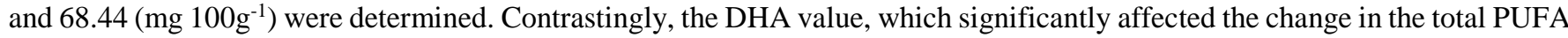

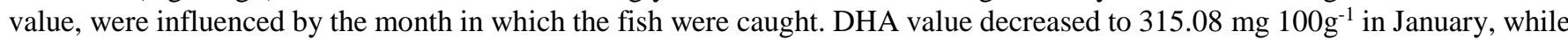

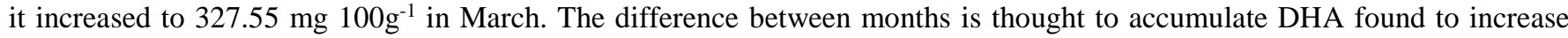
gradually in the body by getting used to the ambient conditions during the stay in the same bay in this fish, which is a migratory species. Seafood contains high and balanced amounts of polyunsaturated fatty acids, especially EPA and DHA (Lunn and Theobald 2006; Ozogul et al. 2009, 2018). Both EPA and DHA are known to be important for human health (Cooner 2000). It was found that this species meets $250-500 \mathrm{mg}$ daily EPA and DHA intake against the risk of cardiovascular disease recommended by EFSA (2012) during the caught in consumption months, Briefly, PUFA value of flesh fish in the March samples (550.96 mg $100 \mathrm{~g}^{-1}$ ) were significantly higher than that in other sample months. Furthermore, fish need PUFA to adapt to lower water temperatures, and cold-sea fish are rich in n-3 fatty acids (Chanmugam et al. 1986).

The n3/n6 ratio in narrow-barred Spanish mackerel fluctuated within the range of 11.39-12.36 and PI, AI and TI values were calculated to determine lipid quality based on fatty acid data. No significant differences in PI, AI and TI values were found among the monthly samples. The AI and TI ratios across the months ranged from 0.81 to 0.87 and from 0.28 to 0.31 , respectively (Table 2). PI values fluctuated within the range of 1.02-0.91 in narrow-barred Spanish mackerel. The n-3/n-6 ratio is a good index to compare the relative nutritional value of fish oil. A higher rate is essential to reduce coronary heart disease, plasma lipid levels and cancer risks (Kinsella et al. 1990). SFAs, MUFAs, and n-6 PUFAs, are TI and AI that these lipids index show potential effects on dietary quality and coronary artery diseases. (Jankowska et al. 2010; Görgün \& Zengin 2015). The findings of many other researchers also have seasonal changes, species, gender, size, food availability, geographic location; breeding status, water temperature and salinity rate affect the amount of fatty acids in other fish species (Vlieg \& Body 1988; Saoud et al. 2008).

\subsection{Amino acids composition of narrow-barred Spanish mackerel}

The amino acid profile of the fresh sample was examined. In the fresh sample, 16 amino acids, including 8 essential amino acids (EAAs) and 9 nonessential amino acids (n-EAA) were detected (Table 3). The amino acids in fish have been very important in terms of nutrition and flavor (Antoine et al. 2001).

When the first sampling results were evaluated, among all the detected amino acids, glutamic acid value was the highest $(3.81 \%)$ and tryptophan value was the lowest $(0.22 \%)$ in January. In the January sample, EAA concentrations from the highest to lowest were as follows: lysine $(2.23 \%)$, leucine $(1.56 \%)$, valine $(1.31 \%)$, histidine $(1.22 \%)$, isoleucine $(1.21 \%)$, threonine $(1.05 \%)$, phenylalanine (1.02), methionine $(0.58 \%)$ and tryptophan $(0.19 \%)$. Among all the EAAs in the fish fillet samples, the concentrations of lysine and leucine were the highest at $2.23 \%$ and $1.56 \%$, respectively, while the concentration of tryptophan was the lowest. Similar results on amino acid content were reported by Paratama et al. 2017. These results are Peng et al. (2013) shows that the highest leucine and lysine in the yellow fin tuna from the Serranidae family. Amino acid composition determines the quality of a protein, which is among the most important macronutrients in human diet. Leucine, valine, isoleucine and lysine are categorized as EAAs because a human body cannot produce them $\mathrm{s}$ on its own; these EAAs are derived from various external food sources and it is well known that each of the amino acids contributes to the basic taste of a product. Among the n-EAAs in the fish fillet samples, the concentrations of glutamic acid and aspartic acid were the highest at $3.81 \%$ and $2.23 \%$, respectively (Table 3). In February, during the second sampling, the concentrations of only some amino acids were changed. The total value of methionine $(0.64 \%)$, leucine $(1.86 \%)$ and lysine $(2.67 \%)$ were increased, and that of histidine $(1.12 \%)$ and isoleucine $(1.01 \%)$ was decreased in the fresh fillet; these values were significantly different across the sampling times. Among the n-EAAs in fish fillet samples from February, there was a significant difference in the concentrations of glutamic acid and aspartic acid, which decreased and increased at 3.43\% and $2.63 \%$, respectively. Data analysis revealed that the concentrations of histidine (1.25\%), methionine $(0.74 \%)$, isoleucine $(1.38 \%)$ and leucine $(1.93 \%)$ increased, whereas that of lysine $(2.02 \%)$ decreased significantly $(\mathrm{P}>0.05)$ in the March samples. On the other hand, the n-EAAs, glutamic acid (2.01\%) and aspartic acid (2.10\%), significantly decreased in the March samples (Table 3). The presence of glycine, alanine, valine, leucine, tyrosine and phenylalanine in the peptides also gives a bitter taste, since proline mostly gives the bitter taste of peptides. The taste of glycine and alanine are active ingredients, and it is well known to have sweetness in various seafood (Pratama et al. 2017). Aspartic acid and glutamic acid have an important role in enzyme active cores, and maintain the solubility properties of proteins (Sikorski et al. 1990; Belitz et al. 2001). Glutamate gives umami taste when its concentration in the foodstuff rises above the taste threshold, and this may be 
an indicator of protein intake (Kawai et al. 2009; Zhao et al. 2016). Also, the less glutamic acid contained in fish meat it would result in less savory taste of the fish meat (Suryaningrum et al. 2010). Non-essential amino acids can be synthesized by transferring an amino group to $\alpha$-keto acids that can be derived from non-protein sources such as glucose (Webster and Lim 2002; Litwack 2017). This may be the cause of non-essential amino acids that increase at sampling times.

Table 3- Amino Acids Composition of narrow-barred Spanish Mackerel

\begin{tabular}{cccc}
\hline Amino Acids & \multicolumn{3}{c}{ Amino Acids profile of mackerel (\%) } \\
\cline { 2 - 4 } & 19 -January & 19 -February & 19 - March \\
\hline Histidine & $1.23 \pm 0.21^{\mathrm{a}}$ & $1.12 \pm 0.29^{\mathrm{b}}$ & $1.25 \pm 0.10^{\mathrm{a}}$ \\
Threonine & $1.05 \pm 0.01$ & $1.04 \pm 0.08$ & $1.04 \pm 0.14$ \\
Methionine & $0.58 \pm 0.03^{\mathrm{b}}$ & $0.64 \pm 0.11^{\mathrm{ab}}$ & $0.74 \pm 0.01^{\mathrm{a}}$ \\
Valine & $1.30 \pm 0.18$ & $1.30 \pm 0.18$ & $1.35 \pm 0.18$ \\
Phenylalanine & $1.02 \pm 0.04$ & $1.02 \pm 0.01$ & $0.99 \pm 0.10$ \\
Isoleucine & $1.31 \pm 0.32^{\mathrm{a}}$ & $1.01 \pm 0.02^{\mathrm{b}}$ & $1.38 \pm 0.32^{\mathrm{a}}$ \\
Leucine & $1.56 \pm 0.26^{\mathrm{b}}$ & $1.86 \pm 0.06^{\mathrm{a}}$ & $1.93 \pm 0.17^{\mathrm{a}}$ \\
Lysine & $2.23 \pm 0.08^{\mathrm{ab}}$ & $2.67 \pm 0.06^{\mathrm{a}}$ & $2.02 \pm 0.16^{\mathrm{b}}$ \\
Tryptophan & $0.22 \pm 0.01$ & $0.24 \pm 0.01$ & $0.24 \pm 0.01$ \\
\hline Serine & $1.88 \pm 0.03$ & $1.86 \pm 0.03$ & $1.81 \pm 0.93$ \\
Glycine & $1.13 \pm 0.02$ & $1.16 \pm 0.0$ & $1.13 \pm 0.12$ \\
Aspartic Acid & $2.23 \pm 0.00^{\mathrm{ab}}$ & $2.63 \pm 0.00^{\mathrm{a}}$ & $2.10 \pm 0.44^{\mathrm{b}}$ \\
Glutamic Acid & $3.81 \pm 0.02^{\mathrm{a}}$ & $3.43 \pm 0.02^{\mathrm{b}}$ & $2.01 \pm 0.75^{\mathrm{c}}$ \\
Arginine & $1.29 \pm 0.20$ & $1.26 \pm 0.14$ & $1.26 \pm 0.90$ \\
Alanine & $1.42 \pm 0.10$ & $1.40 \pm 0.10$ & $1.40 \pm 0.10$ \\
Tyrosine & $0.78 \pm 0.12$ & $0.76 \pm 0.12$ & $0.77 \pm 0.12$ \\
\hline
\end{tabular}

For the data relative to fish fillet, values are mean \pm SD. $(n=6$; number of fishes per sampling time); and values in the same row with different superscript letters indicate statistically significant difference $(\mathrm{P}<0.05)$

In conclusion, the present study demonstrates that narrow-barred Spanish mackerel, which are caught and landed in the northeastern Mediterranean Sea, have a commercial value and are rich in proteins, fatty acid and amino acids during the sampling time. Moreover, the amounts of EPA and n3/n6 were not significantly different at all sampling times. This species has been found to meet the daily intake of $250-500 \mathrm{mg}$ of EPA and DHA against the risk of cardiovascular disease recommended by EFSA (2012) caught during the months of consumption. This fish can be recommended in terms of detected essential fatty acid and amino acid profile that completely nutritious for the human as well as other organisms' dietary requirements.

\section{References}

Aktaş H \& Halperin J A (2004). Translational regulation of gene expression by $\omega$-3 fatty acids. The Journal of nutrition 134(9): 2487S-2491S https://doi.org/10.1093/jn/134.9.2487S

Akyol O \& Tosunoğlu Z (2019). On the Occurrence of a Lessepsian immigrant Scomberomorus commerson (Scombridae) in Izmir Bay (Aegean Sea, Turkey. Ege Journal of Fisheries and Aquatic Sciences 36(1): 81-84 https://doi.org/10.12714/egejfas.2019.36.1.10

Antoine F R, Wei C I, Littell R C, Quinn B P, Hogle A D \& Marshall M R (2001). Free amino acids in dark-and white-muscle fish as determined by o-phthaldialdehyde precolumn derivatization. Journal of food science 66(1): 72-77 https://doi.org/10.1111/j.1365-2621.2001.tb15584.x

AOAC (1995). Official Methods of Analysis. 16 $6^{\text {th }}$ (Eds). Washington, D.C.: Association of Official Analytical Chemists

Arts M T, Ackman R G \& Holub B J (2001). Essential fatty acids in aquatic ecosystems: A crucial link between diet and human health and evolution. Can. J. Fish. Aquat. Sci. 58: 122-137 https://doi.org/10.1139/f00-224

Bandarra N M, Batista I, Nunes M L \& Empis J M (2001). Seasonal variations in the chemical composition of horse mackerel (Trachurus trachurus). European Food Research and Technology 212: 535-539 https://doi.org /10.1007/s002170100299

Belitz H D, Grosch W \& Schieberle P (2001). Lehrbuch der Lebensmittelchemie, 5. Aufl. Springer, Berlin Heidelberg and New York

Canto A C, Costa-Lima B R, Suman S P, Monteiro M L G, Marsico E T, Conte-Junior C A \& Silva T J (2015). Fatty acid profile and bacteriological quality of caiman meat subjected to high hydrostatic pressure. LWT-Food Science and Technology 63(2): 872-877 https://doi.org/10.1016/j.lwt.2015.05.003

Çelik M (2008). Seasonal changes in the proximate chemical compositions and fatty acids of chub mackerel (Scomber japonicus) and horse mackerel (Trachurus trachurus) from the north eastern Mediterranean Sea. International Journal of Food Science \& Technology 43: 933938 doi:10.1111/j.1365-2621.2007.01549.x

Chanmugam P, Boudreau M \& Hwang DH (1986). Differences in the $\omega 3$ fatty acid contents in pond-reared and wild fish and shellfish. Journal of Food Science 51(6): 1556-1557 https://doi.org/10.1111/j.1365-2621.1986.tb13859.x

Connor W E (2000). Importance of n-3 fatty acids in health and disease. Am. J. Clin. Nutr 71: 171S-5S https://doi.org/10.1093/ajcn/71.1.171S 
Czesny S \& Dabrowski K (1998). The effect of egg fatty acid concentrations on embryo viability in wild and domesticated walleye (Stizostedion vitreum). Aquatic Living Resources 11(6): 371-378 https://doi.org/10.1016/S0990-7440(99)80002-3

Das U N (2006). Essential fatty acids: biochemistry, physiology and pathology. Biotechnology Journal: Healthcare Nutrition Technology 1(4): 420-439 https://doi.org/10.1002/biot.200600012

Durmuş M (2018). Fish oil for human health: omega-3 fatty acid profiles of marine seafood species. Food Science and Technology https://doi.org/10.1590/fst.21318

EFSA Panel on Dietetic Products, Nutrition and Allergies (NDA) (2012). Scientific opinion on the tolerable upper intake level of eicosapentaenoic acid (EPA), docosahexaenoic acid (DHA) and docosapentaenoic acid (DPA). EFSA Journal 10(7): 2815

Folch J, Lees M \& Stanley G S (1957). A simple method for the isolation and purification of total lipids from animal tissues. Journal of Biological Chemistry 226(1): 497-509

Froese R \& Pauly D (2019). FishBase. World Wide Web electronic publication. www.fishbase.org, version (08/2019)

Fung T T, Rexrode K M, Mantzoros C S, Manson J E, Willett W C \& Hu F B (2009). Mediterranean diet and incidence and mortality of coronary heart disease and stroke in women. Circulation 119(8): 1093-1100 doi: 10.1161/CIRCULATIONAHA.108.816736

Gheshlaghi Z N, Riazi G H, Ahmadian S, Ghafari M \& Mahinpour R (2008). Toxicity and interaction of titanium dioxide nanoparticles with microtubule protein. Acta Biochimica et Biophysica Sinica 40(9): 777-782 https://doi.org/10.1093/abbs/40.9.777

Gökçe M A, Taşbozan O, Çelik M \& Tabakoğlu Ş S (2004). Seasonal variations in proximate and fatty acid compositions of female common sole (Solea solea). Food Chemistry 88(3): 419-423 https://doi.org/10.1016/j.foodchem.2004.01.051

Gökoğlu N, Yerlikaya P \& Cengiz E (2004). Effects of cooking methods on the proximate composition and mineral values of rainbow trout (Oncorhynchus mykiss). Food Chemistry 84(1): 19-22 https://doi.org/10.1016/S0308-8146(03)00161-4

Görgün S \& Zengin G (2015). Determination of fatty acid profiles and esterase activities in the gills and gonads of Vimba vimba (L., 1758). Journal of the American Oil Chemists' Society 92(3): 353-360 https://doi.org/10.1007/s11746-015-2602-y

Gücü A C \& Bingel F (1994). Trawlable species assemblages on the continental shelf of the northeastern Levant Sea (Mediterranean) with an emphasis on Lesseptian migration. Acta Adriatica 35(1): 83-100

Hellberg R S, DeWitt C A M \& Morrissey M T (2012). Risk-benefit analysis of seafood consumption: a review. Comprehensive Reviews in Food Science and Food Safety 11(5): 490-517 https://doi.org/10.1111/j.1541-4337.2012.00200.x

Horn S S, Ruyter B, Meuwissen T H, Hillestad B \& Sonesson A K (2018). Genetic effects of fatty acid composition in muscle of Atlantic salmon. Genetics Selection Evolution 50(1): 23

Hornell J (1935). Report on the fisheries of Palestine

Huynh M D \& Kitts D D (2009). Evaluating nutritional quality of pacific fish species from fatty acid signatures. Food Chemistry 114(3): 912918 https://doi.org/10.1016/j.foodchem.2008.10.038

Jankowska E A, Rozentryt P, Witkowska A, Nowak J, Hartmann O, Ponikowska B \& McMurray J J (2010). Iron deficiency: an ominous sign in patients with systolic chronic heart failure. European Heart Journal 31(15): 1872-1880 https://doi.org/10.1093/eurheartj/ehq158

Kawai M, Uneyama H \& Miyano H (2009) Taste-active components in foods, with concentration on umami compounds Journal of Health Science 55: 667-73 https://doi.org/10.1248/jhs.55.667

Kinsella J E, Broughton K S \& Whelan J W (1990). Dietary unsaturated fatty acids: interactions and possible needs in relation to eicosanoid synthesis. The Journal of Nutritional Biochemistry 1(3): 123-141 https://doi.org/10.1016/0955-2863(90)90011-9

Köşker A R (2020). Metal and fatty acid levels of some commercially important marine species from the northeastern Mediterranean: benefits and health risk estimation. Environmental Monitoring and Assessment 192: 1-16

Lauritzen L, Hansen H S, Jorgensen M H \& Michaelsen K F (2001). The essentiality of long chain n-3 fatty acids in relation to development and function of the brain and retina. Prog. Lipid Res 40: 1-94

Lazo O, Guerrero L, Alexi N, Grigorakis K, Claret A, Pérez J A \& Bou R (2017). Sensory characterization, physico-chemical properties and somatic yields of five emerging fish species. Food Research International 100: 396-406 https://doi.org/10.1016/j.foodres.2017.07.023

Litwack G (2017). Human biochemistry. Academic Press

Lunn J \& Theobald H E (2006). The health effects of dietary unsaturated fatty acids. Nutrition Bulletin 31(3): 178-224 https://doi.org/10.1111/j.1467-3010.2006.00571.x

Nordov A, Marchioli R, Arnesen H \& Videbaek J (2001). N-3 polyunsaturated fatty acids and cardiovascular diseases. Lipids 36: 127-129 https://doi.org/10.1007/s11745-001-0695-7

Osman H, Suriah A R \& Law E C (2001). Fatty acid composition and cholesterol value of selected marine fish in Malaysian waters. Food Chemistry 73(1): 55-60 https://doi.org/10.1016/S0308-8146(00)00277-6

Ozogul Y, Ozogul F H, Çiçek E, Polat A \& Kuley E (2009). Fat content and fatty acid compositions of 34 marine water fish species from the Mediterranean Sea. International Journal of Food Sciences and Nutrition, 60(6): 464-475 https://doi.org/10.1080/09637480701838175

Ozogul Y, Ucar Y, Takadaş F, Durmus M, Köşker A R \& Polat A (2018). Comparision of green and conventional extraction methods on lipid yield and fatty acid profiles of fish species. European Journal of Lipid Science and Technology, 120(12): 1800107 https://doi.org/10.1002/ejlt.201800107

Patrick Saoud I, Batal M, Ghanawi J \& Lebbos N (2008). Seasonal evaluation of nutritional benefits of two fish species in the eastern Mediterranean Sea. International Journal of Food Science \& Technology 43(3): 538-542 https://doi.org/10.1111/j.13652621.2006.01491.x

Peng S, Chen C, Shi Z \& Wang L (2013). Amino acid and fatty acid composition of the muscle tissue of yellowfin tuna (Thunnus albacares) and bigeye tuna (Thunnus obesus). Journal of Food and Nutrition Research 1(4): 42-45 DOI:10.12691/jfnr-1-4-2

Prato E \& Biandolino F (2012). Total lipid content and fatty acid composition of commercially important fish species from the Mediterranean, Mar Grande Sea. Food Chemistry 131(4): 1233-1239 https://doi.org/10.1016/j.foodchem.2011.09.110

Puwastien P, Judprasong K, Kettwan E, Vasanachitt K, Nakngamanong Y \& Bhattacharjee L (1999). Proximate composition of raw and cooked Thai freshwater and marine fish. Journal of Food Composition and Analysis 12(1): 9-16 https://doi.org/10.1006/jfca.1998.0800

Rajaram R, Maruthamuthu A \& Metillo E B (2018). Fatty acid profiling of commercially important raw and boiled seer fish Scomberomorus commerson (Lacepede, 1800) (Scombridae, Teleostei, Pisces). In Proceedings of the Zoological Society (Vol. 71, No. 2, pp. 146-152). Springer India https://doi.org/10.1007/s12595-017-0222-2

Santos-Silva J, Bessa R J B \& Santos-Silva F (2002). Effect of genotype, feeding system and slaughter weight on the quality of light lambs: II. Fatty acid composition of meat. Livestock Production Science 77(2-3): 187-194 https://doi.org/10.1016/S0301-6226(02)00059-3 
Saoud P I, Batal M, Ghanawi J \& Lebbos N (2008). Seasonal evaluation of nutritional benefits of two fish species in the eastern Mediterranean Sea. International Journal of Food Science \& Technology 43(3): 538-542 https://doi.org/10.1111/j.1365-2621.2006.01491.x

Sebranek J (2009). Basic curing ingridients. In: Tarte R, (ed.) Ingredients in Meats Product. Properties Functionality and Applicatons. New York: Springer Scince https://doi.org/10.1007/978-0-387-71327-4

Sikorski Z E, Kolakowska A \& Pan B S (1990). The nutritive composition of the major groups of marine food organisms. In: Resources Nutritional Composition and Preservation. Ed., SIKORSKI, 1990, CRC Press-Inc., Boca Raton, FL, pp. 30-52

Silvers K M \& Scott K M (2002). Fish consumption and self-reported physical and mental health status. Public Health Nutr. 5: 427-431 https://doi.org/10.1079/PHN2001308

Torcu H \& Mater S (2000). Lessep- sian fishes spreading along the coasts of the Mediterranean and the Southern Aegean Sea of Turkey. Turkish Journal of Zoology 24: 139-148

Turchini G M, Francis D S \& De Silva S S (2007) A whole body,in vivo, fatty acid balance method to quantify PUFA metabolism (desaturation, elongation and beta-oxidation). Lipids 42:1065-1071 https://doi.org/10.1007/s11745-008-3213-2

Türkmen M, Türkmen A, Tepe Y, Ateş A \& Gökkuş K (2008). Determination of metal contaminations in sea foods from Marmara, Aegean and Mediterranean seas: twelve fish species. Food Chemistry 108(2): 794-800 https://doi.org/10.1016/j.foodchem.2007.11.025

Vijayan D K, Jayarani R, Singh D K, Chatterjee N S, Mathew S, Mohanty B P \& Anandan R (2016). Comparative studies on nutrient profiling of two deep sea fish (Neoepinnula orientalis and Chlorophthalmus corniger) and brackish water fish (Scatophagus argus). The Journal of Basic \& Applied Zoology 77: 41-48 https://doi.org/10.1016/j.jobaz.2016.08.003

Vlieg P \& Body D R (1988). Lipid contents and fatty acid composition of some New Zealand freshwater finfish and marine finfish, shellfish, and roes. New Zealand Journal of Marine and Freshwater Research 22(2): 151-162 https://doi.org/10.1080/00288330.1988.9516287

Von Schacky C, Angerer P, Kothny W, Theisen K \& Mudra H (1999). Effect of dietary omega-3 fatty acids on coronary atherosclerosis: A randomized double-blind placebo-controlled trial. Ann. Int. Med. 130: 554-562 DOI: 10.7326/0003-4819-130-7-199904060-00003

Webster C D \& Lim C (Eds.) (2002). Nutrient requirements and feeding of finfish for aquaculture. Cabi

Weihrauch J L, Posati L P, Anderson B A \& Exler J (1977). Lipid conversion factors for calculating fatty acid contents of foods. Journal of the American Oil Chemists' Society 54(1): 36-40 https://doi.org/10.1007/BF02671370

Zhao C J, Schieber A \& Gänzle M G (2016). Formation of taste-active amino acids, amino acid derivatives and peptides in food fermentationsA review. Food Research International 89: 39-47 https://doi.org/10.1016/j.foodres.2016.08.042

(C) 2021 by the authors. Licensee Ankara University, Faculty of Agriculture, Ankara, Turkey. This article is an open access article distributed under the terms and conditions of the Creative Commons Attribution (CC BY) license (http://creativecommons.org/licenses/by/4.0/). 